\title{
Tinjauan Kasus COVID-19 Berdasarkan Jenis Kelamin, Golongan Usia, dan Kepadatan Penduduk di Kabupaten Pati
}

\section{Overview of COVID-19 Cases by Gender, Age Group, and Population Density in Pati Regency}

\author{
Aeda Ernawati 1)a)* \\ 1)Badan Perencanaan Pembangunan Daerah Kabupaten Pati \\ a)Jl. Raya Pati-Kudus Km. 3,5 Pati. 59163. Jawa Tengah \\ *Email: aeda.ernawati76@gmail.com
}

\begin{abstract}
COVID-19 spread out rapidly and it has caused a lot of mortality among the victims. Objectives of the research are to describe the COVID-19 cases based on the gender, and age group in the study area and to analyze the effect of population density on COVID-19 cases. The study used quantitative descriptive approach. The study used secondary data available at BPS, the Health Office, and the COVID-19 task force website in Pati Regency. It used a descriptive analysis and also a statistical test, namely a simple linear regression test. The results showed that 53\% of COVID-19 victims are males. Most cases of COVID-19 attacked the productive agers, mainly at the ages of 46-59 years old consisting of 637 people (36.59\%). Based on data up to November 1st, 2021, the most COVID-19 sufferers in Pati District are 1857 people. Based on the regression test, there is an effect of population density on the highly accident cases of COVID-19. There is a strong influence of population density on the COVID-19 cases with a correlation coefficient $(R)$ of 0.890 and a coefficient of determination (R2) of 0.793. It means that 79\% of COVID-19 sufferers are influenced by population density. Therefore, prevention efforts must be carried out through counseling to male people in order not to smoke and increase the application of health protocols. In addition, prevention for elder people is conducted by increasing body resistance by fulfilling food intake and vaccination.
\end{abstract}

Keywords: age group, COVID-19, gender, population density

\begin{abstract}
ABSTRAK
COVID-19 menyebar dengan cepat dan menyebabkan banyak kematian pada masyarakat yang terpapar. Tujuan penelitian untuk mengambarkan kasus COVID-19 di Kabupaten Pati berdasarkan jenis kelamin, golongan usia, dan kecamatan serta untuk menganalisis pengaruh kepadatan penduduk terhadap kasus COVID-19. Penelitian menggunakan pendekatan deskriptif kuantitatif. Penelitian menggunakan data sekunder yang tersedia di BPS, Dinas Kesehatan, dan website gugus tugas COVID-19 di Kabupaten Pati. Analisis secara deskriptif dan untuk kepadatan dilakukan uji statistik dengan menggunakan uji regresi linear sederhana. Hasil penelitian menunjukkan 53\% penderita COVID-19 berjenis kelamin laki-laki. Kasus COVID-19 sebagian besar menyerang usia produktif, terbanyak pada golongan usia 46-59 tahun yaitu sebanyak 637 orang (36,59\%). Berdasarkan data per 1 November 2021, penderita COVID-19 paling banyak Kecamatan Pati yaitu sebanyak 1857 orang. Hasil uji regresi menunjukkan ada pengaruh kepadatan penduduk dengan tingginya kasus COVID-19. Ada pengaruh yang kuat kepadatan penduduk terhadap tingginya kasus COVID-19 dengan koefisien korelasi $(R)$ sebesar 0,890 dan nilai koefisien determinasi (R2) sebesar 0,793, artinya 79\% tingginya jumlah penderita COVID-19 dipengaruhi oleh kepadatan penduduk. Upaya pencegahan harus selalu dilakukan melalui penyuluhan pada laki-laki untuk tidak merokok dan meningkatkan penerapan protokol kesehatan. Pencegahan pada lansia dengan meningkatkan daya tahan tubuh dengan memenuhi asupan makanan dan melakukan vaksinasi.
\end{abstract}

Kata kunci: COVID-19, golongan usia, jenis kelamin, kepadatan penduduk

\section{PENDAHULUAN}

Coronavirus disease 2019 atau COVID-19 adalah salah satu penyakit menular yang disebabkan oleh virus corona. COVID-19 ditemukan di akhir tahun 2019 di Kota Wuhan Tiongkok (Illah, 2021). Penularan COVID-19 sangat cepat. COVID-19 sudah menyebar di 144 
negara pada awal Maret 2020 (Tuwu et al., 2021). COVID-19 ditetapkan WHO sebagai pandemi global sejak tanggal 11 Maret 2020 setelah jumlah penderita COVID-19 di seluruh dunia mencapai 121.000 orang (Ghiffari, 2020; Ilpaj \& Nurwati, 2020). Selanjutnya WHO melaporkan pada tanggal 25 Maret 2020 bahwa COVID-19 sudah menyebar di 192 negara COVID-19 dengan kasus konfirmasi sebesar 414.179 kasus dan angka kematian sebesar 18.440 kematian, artinya Case Fatalily Rate (CFR) dari COVID-19 sebesar 4,4\% (Susanto, 2021). Laporan WHO per tanggal 10 April 2020 menyebutkan sebanyak 212 negara telah terpapar COVID-19 dengan total kasus positif COVID-19 sebanyak 1.439 .516 orang dan 85.711 orang meninggal (Siagian, 2020).

Adapun kasus COVID-19 pertama kali di Indonesia dilaporkan pada tanggal 2 Maret 2020. Kasus COVID-19 awalnya terkonfirmasi pada dua orang yang terinfeksi karena memiliki riwayat perjalanan dari suatu negara terjangkit (Sari, Yaslina, \& Suryati, 2020). Selanjutnya kasus COVID-19 terus menyebar di 34 provinsi di Indonesia. Kasus COVID-19 terus meningkat. Laporan Indonesia pada tanggal 12 April 2020 menyebutkan kasus konfirmasi COVID-19 sebanyak 4.241 kasus (Susanto, 2021). Jumlah penderita COVID-19 di Indonesia per tanggal 14 November 2020 sebanyak 463.007 jiwa dengan jumlah kasus yang meninggal sebanyak 15.148 jiwa (Rahmi et al., 2020). Data per tanggal 11 Februari 2021 menunjukkan kasus positif sebanyak 1.183.555 orang dengan jumlah pasien COVID-19 yang sembuh sebanyak 982.972 orang, dan meninggal sebanyak 32.167 orang. Provinsi DKI Jakarta merupakan provinsi dengan kasus terbanyak disusul Jawa Barat pada posisi kedua, dan Jawa Tengah dalam posisi ketiga. Jumlah penderita COVID-19 di Jawa Tengah sebanyak 138.547 orang atau 11,7\% dari total kasus di Indonesia (Sofianto, 2021).

Adanya pandemi COVID-19 memberikan dampak bagi semua sektor kehidupan. Dampak nyata terlihat pada sektor kesehatan, sosial, dan ekonomi (Aeni, 2021). Dampak pandemi COVID-19 pada sektor kesehatan ditandai menurunnya cakupan layanan kesehatan. Dampak COVID-19 pada sektor sosial ditunjukkan oleh meningkatnya angka kemiskinan. Adapun dampak COVID-19 pada sektor ekonomi berupa pertumbuhan ekonomi yang menurun. Dampak COVID-19 pada sektor pendidikan antara lain adanya gangguan dalam proses belajar mengajar siswa karena adanya penutupan sekolah dalam jangka waktu yang lama untuk mencegah penularan COVID-19 (Amalia \& Sa'adah, 2020). Kendala yang dihadapi antara lain keterbatasan guru maupun siswa terkait dengan kemampuan penyesuaian diri dan kemampuan penguasaan teknologi informasi yang digunakan dalam proses pembelajaran. Selain itu sarana dan prasarana yang kurang memadai baik dari sekolah maupun siswa termasuk akses internet yang terbatas.

Kabupaten Pati merupakan salah satu kabupaten di Provinsi Jawa Tengah yang pernah masuk dalam zona merah COVID-19 dan menjadi kabupaten dengan kasus kematian tertinggi (Aeni, 2021). Data per tanggal 12 Februari 2021 menunjukkan jumlah kasus terkonfirmasi positif di Kabupaten Pati pada waktu yang sama sebanyak 1.986 orang dengan rincian 48 dirawat, 1.614 sembuh dan 324 meninggal. Sampai saat ini kasus baru COVID19 masih muncul. Belum ada yang tahu kapan pandemi COVID-19 akan berakhir. Oleh karena itu upaya untuk pencegahan dan memutus penularan harus terus dilakukan dengan memperhatikan beberapa aspek, salah satunya aspek demografi. Kajian dalam aspek demografi sangat penting dalam mengidentifikasi kelompok rentan COVID-19 di Kabupaten Pati. Diharapkan upaya penanganan COVID-19 menjadi lebih tepat sasaran. Tujuan penelitian untuk menggambarkan kasus COVID-19 di Kabupaten Pati berdasarkan jenis kelamin, golongan usia, dan kecamatan serta menganalisis pengaruh kepadatan penduduk terhadap kasus COVID-19. 


\section{TINJAUAN PUSTAKA}

\section{Coronavirus Disease 19 (COVID-19)}

Coronavirus Disease 2019 (COVID-19) merupakan penyakit yang disebabkan oleh virus Severe Acute Repiratory Syndrome Coronavirus 2 (SARS-CoV-2). SARS-CoV-2 merupakan virus baru yang ditemukan pada akhir tahun 2019. COVID-19 merupakan jenis penyakit baru yang sebelumnya belum pernah ada. Virus (SARS-CoV-2) menyerang sistem pernapasan. Virus ini dapat menyebabkan pneumonia akut bahkan dapat menimbulkan kematian (Sari et al., 2020).

COVID-19 ditularkan melalui beberapa cara. Pertama, COVID-19 ditularkan melalui droplet atau tetesan caian yang berasal dari batuk atau bersin. Kedua, COVID-19 ditularkan karena ada kontak langsung (menyentuh dan berjabat tangan) dengan penderita COVID-19 orang seperti. Ketiga, menyentuh benda yang terkontaminasi virus COVID-19 kemudian tangan menyentuh mulut atau hidung atau mata sebelum mencuci tangan (Kemenkes RI, 2020).

\section{Gejala Klinis}

Masa inkubasi (waktu antara paparan virus sampai munculnya gejala) COVID-19 ratarata selama 5-6 hari, namun dapat mencapai 14 hari. Gejala klinis yang utama adalah demam $>38 \%$, batuk, pilek, sakit tenggorokan, letih, lesu, dan sesak napas (Kemenkes RI, 2020).

Klasifikasi COVID-19 berdasarkan tingkat keparahan kasus dibagi menjadi: 1) COVID-19 tanpa gejala; 2) COVID-19 dengan gejala ringan; 3) COVID-19 dengan gejala sedang; 4) COVID19 dengan gejala berat; dan COVID-19 dalam kondisi kritis. Penderita COVID-19 paling ringan adalah kondisi penderita tidak ditemukan gejala apapun. Penderita COVID-19 dengan kondisi ringan menunjukkan ada gejala tapi tidak ada bukti pneumonia virus atau tanpa hipoksia. Muncul gejala seperti demam, batuk, fatigue, anoreksia, napas pendek, kelelahan. Muncul gejala lain yang tidak spesifik lainnya seperti sakit tenggorokan, kongesti hidung, sakit kepala, diare, mual dan muntah, serta hilang pembauan dan pengecapan. Adapun pasien yang kritis ditandai adanya Acute Respiratory Distress Syndrome (ARDS), sepsis dan syok sepsis (PDPI, PERKI, PAPDI, PERDATIN, \& IDAI, 2020).

Pasien COVID-19 dapat sembuh jika segera mendapat penanganan. Semakin ringan gejala yang dirasakan pasien, semakin cepat proses penyembuhannya. Penderita COVID-19 dengan gejala ringan dapat sembuh dalam waktu sekitar satu pekan. Adapun penderita COVID-19 yang parah dapat mengalami gagal napas yang dapat menyebabkan kematian. Tingkat keparahan COVID-19 dipengaruhi oleh daya tahan tubuh, usia, dan penyakit yang diderita sebelumnya seperti hipertensi, diabetes, jantung, asma, dll. Angka kematian tinggi pada penderita yang sudah lanjut usia karena adanya penyakit bawaan seperti kardiovaskular, hipertensi, diabetes mellitus, dan parkinson (Levani, Prastya, \& Mawaddatunnadila, 2021).

\section{Diagnosis}

Seseorang yang dinyatakan terkonfirmasi COVID-19 ditentukan berdasarkan hasil wawancara dokter dengan keluarga pasien terkait dengan adanya riwayat perjalanan seseorang dari daerah terjangkit, tanda-tanda dan gejala klinis yang muncul serta dikuatkan oleh pemeriksaan laboratorium. Upaya pengendalian kasus perlu didukung oleh hasil pemeriksaan laboratorium yang cepat dan akurat. Ada beberapa cara untuk mendeteksi infeksi COVID-19, yaitu quantitative RTPolymerase chain reaction (qRT-PCR), Rapid Antigen SARS-COV2, CT-Scan, dan Ge Nose. Masing-masing memiliki cara kerja sendiri.

Kuantitatif RT-PCR merupakan cara mendiagnosa COVID-19 menggunakan metode molekuler. Kuantitatif RT-PCR memiliki banyak kelebihan, diantaranya lebih spesifik, konsisten, dapat digunakan dengan mudah, hanya memerlukan primer-probe tertentu yang dirancang dan disintesis sesuai gen target. Banyak pabrik 
yang sudah merancang alat kuantitatif RT-PCR dengan gen target yang berbeda Oleh karena itu salah satu kelemahannya adalah setiap alat tes memiliki variasi tingkat sensitivitas yang berbeda. Kelemahan lain adalah membutuhkan biaya yang besar untuk menjamin keselamatan petugas dan mutu hasil pemeriksaan. Biaya yang besar terkait dengan pemrosesan sampel, transportasi, proses ekstraksi asam nukleat, penyediaan ruangan yang bertekanan negatif, peralatan laboratorium yang handal, dan peralatan pendukung lainnya. Selain itu, alat PCR tidak hanya dapat mendeteksi virus penyebab COVID-19, tetapi bisa deteksi beberapa virus pernapasan secara bersamaan sehingga menyebabkan adanya risiko positif palsu atau negatif palsu.

Rapid Antigen SARS-COV2 merupakan metode pemeriksaan imunoserologi yang mudah digunakan. Antigen-Rapid Detection Test (Ag-RDT) terdiri dari kaset plastik dengan rongga sampel dan penyangga serta strip matriks nitroselulosa disertai penanda berupa garis uji. Sampel yang dipakai untuk Ag-RDT adalah sampel usapan nasal atau nasofaringeal. Salah satu kelebihan metode Rapid Antigen SARS-COV2 yaitu tes lebih sederhana, mudah dilakukan, serta waktu pemeriksaan yang cepat sekitar 10-30 menit. Adapun kelemahan Rapid Antigen SARS-COV2 adalah memiliki sensitivitas yang lebih rendah daripada metode molekuler. Hal tersebut dikarenakan uji cepat antigen memiliki batas deteksi minimum jumlah virus. Oleh karenanya, hasil pemeriksaan Rapid Antigen SARS-COV2 sebaiknya dikonfirmasi dengan pemeriksaan RT-PCR

CT Scan juga merupakan salah satu teknik diagnosis yang memiliki sensitivitasnya tinggi. Gambar CT Scan dada pasien yang terinfeksi COVID-19 bersifat khas. CT Scan ditemukan sebagai alat diagnostik yang bagus untuk skrining pasien COVID-19 terutama di daerah prevalensi atau pandemi yang tinggi. CT Scan memiliki kelemahan tidak mampu memisahkan kasus COVID-19 dengan pneumonia lain (virus atau non-virus) sehingga tidak dapat digunakan untuk mengonfirmasi penyebab penyakit dalam diagnosis COVID-19. Karena itu, CT Scan digunakan sebagai salah satu metode diagnostik tambahan untuk mendiagnosis COVID-19.

Salah satu metode terbaru dalam mendeteksi infeksi COVID-19 adalah Ge Nose. Ge Nose dikembangkan oleh Universitas Gadjah Mada. Cara kerja Ge Nose adalah mendeteksi Volatile Organic Compound (VOC) yang terbentuk karena adanya infeksi COVID-19. VOC keluar saat bernafas dan masuk dalam kantong khusus. Udara dalam kantong khusus tersebut selanjutnya diidentifikasi dengan cara khusus melalui sensor-sensor. Ge Nose telah diuji secara klinis di delapan rumah sakit dengan total sampel 1999. Hasil uji klinis menunjukkan bahwa alat ini memiliki sensitivitas antara 8992\% dengan spesifitas 95-96\% (Gunardi, 2021).

\section{Cara Pencegahan}

Cara mencegah penularan COVID-19 secara individu antara lain dengan: 1) menjaga jarak secara fisik (physical distancing); 2) tidak berdekatan dengan orang yang belum jelas status kesehatannya atau mengatur jarak minimal 1-2 meter; 3) bekerja dari rumah; 4) melaksanakan etika batuk; 5) membiasakan Cuci Tangan Pakai Sabun (CTPS); 6) menggunakan masker jika sakit dan saat keluar rumah; 7) menghindari berkumpul massal atau berkerumun; 8) menghindari bepergian keluar kota/luar negeri; 9) tidak mengunjungi orangtua/lanjut usia; dan 10) meningkatkan daya tahan tubuh melalui praktek pola hidup bersih dan sehat (PHBS) seperti konsumsi gizi seimbang, olah raga minimal 30 menit sehari, istirahat yang cukup (Ridwan, Darmawati, \& Rahmawati, 2020).

Physical distancing merupakan upaya untuk mengurangi interaksi orang yang terinfeksi COVID-19 dengan orang yang sehat dengan tujuan untuk mengurangi atau menghentikan penularan COVID-19. Physical 
Distancing efektif dalam mencegah penularan penyakit yang ditularkan melalui kontak fisik seperti menyentuh permukaan benda yang terkontaminasi, atau penyakit yang ditularkan melalui udara termasuk COVID-19.

Social distancing merupakan upaya untuk mencegah penyebaran COVID-19 dengan melakukan pembatasan kegiatan sosial bagi warga dalam suatu daerah yang diduga terinfeksi penyakit. Warga diminta untuk menjaga jarak setidaknya 1-2 meter saat berkomunikasi langsung dengan orang lain khususnya dengan seseorang yang sedang sakit atau kelompok yang rentan terpapar COVID-19. Selain itu, warga dilarang berjabat tangan selama pandemi.

Penerapan social distancing di masyarakat antara lain orang tua bekerja dari rumah (work from home), anak, dan mahasiswa belajar di rumah, tidak melakukan kegiatan yang mendatangkan banyak orang, serta tidak menjenguk orang yang sedang sakit. Komunikasi cukup dengan telepon atau media lain yang tidak memerlukan kontak fisik (Kresna \& Ahyar, 2020).

Penularan COVID-19 dapat terjadi melalui tangan yaitu ketika memegang sesuatu atau berjabat tangan. Virus COVID-19 dapat masuk ke tubuh kita melalui mulut, lubang hidung, mata, atau liang telinga. Hal ini dapat terjadi karena adanya kebiasaan memasukkan jari ke hidung, mengucek mata, mengorek liang telinga ketika kita belum melakukan cuci tangan (Zuhroidah, Toha, \& Sujarwadi, 2021). Selain itu, etika batuk juga perlu diperhatikan. Etika batuk yaitu hidung dan mulut ditutup dengan tisu, selanjutnya tisu dibuang ke tempat sampah (Arif et al., 2020).

Masker merupakan alat pelindung diri untuk menutupi hidung dan mulut agar terhindar dari COVID-19. Masker harus dipakai saat keluar rumah. Masker juga menjadi pelindung saat berinteraksi dengan orang lain yang tidak diketahui status kesehatannya (Ridwan et al., 2020).
Masih ada satu lagi upaya pencegahan COVID-19 yaitu vaksinasi. Dalam rangka mengurangi angka morbiditas dan mortalitas serta membentuk kekebalan kelompok terhadap virus COVID-19, maka dilakukan program vaksinasi. Vaksin sudah diuji keamanannya sehingga tidak menyebabkan masalah kesehatan, baik pada saat vaksinasi maupun setelahnya. Adapun jenis-jenis vaksin yang diuji keamanannya dan hasilnya aman untuk digunakan diantaranya Sinophram, Pfizer, AstraZeneca, Moderna, Jessen, dan Sinovac (Nugroho \& Hidayat, 2021).

Sebagian masyarakat ada yang menerima dan ada yang menolak program vaksinasi untuk mencegah COVID-19. Hasil penelitian menyebutkan adanya penolakan masyarakat terhadap vaksinasi COVID-19 karena adanya keraguan dan kecemasan akibat informasi tentang vaksinasi COVID-19 yang kurang memadai. Banyak informasi yang beredar berisi hoax yang menakutkan masyarakat untuk melakukan vaksinasi. Oleh karena itu perlu perbaikan komunikasi antara pemerintah dengan masyarakat (Astuti et al., 2021) .

\section{Faktor Risiko COVID-19}

Ada beberapa faktor yang menyebabkan seseorang lebih mudah terpapar COVID-19. Faktor risiko COVID-19 antara lain: usia, jenis kelamin, orang yang dirawat di rumah sakit, adanya penyakit penyerta (hipertensi, diabetes mellitus, kardiovaskuler, dan paru obstruktif kronik) dan riwayat merokok (Hidayani, 2020). Orang yang berinteraksi langsung dengan penderita COVID-19 juga berisiko tertular COVID19 (Levani et al., 2021). Kepadatan penduduk suatu wilayah juga meningkatkan risiko penduduk terpapar COVID-19 (Edriani, Rahmadani, \& Noor, 2021).

Usia

Usia menjadi salah satu faktor risiko terpapar COVID-19. Orang berusia lebih dari 60 tahun lebih berisiko untuk terpapar COVID-19. 
Orang lanjut usia mengalami proses penurunan fungsi jaringan dan organ tubuh sehingga mereka lebih mudah terserang penyakit. Fungsi organ dan kekebalan tubuh sudah menurun. Umumnya orang yang sudah lanjut usia mengidap penyakit penyerta sehingga kondisinya lemah dan tidak dapat melawan infeksi yang masuk ke dalam tubuh. Elastisitas jaringan paru-paru makin lama makin berkurang. Peradangan yang terjadi pada lansia dapat memberikan efek yang besar bahkan bisa menyebabkan kerusakan organ (Elviani, Anwar, \& Sitorus, 2021).

\section{Jenis Kelamin}

Laki-laki lebih rentan terpapar COVID-19 daripada perempuan. Laki-laki biasanya lebih banyak keluar rumah karena faktor pekerjaan. Faktor lainnya adalah faktor kromosom dan hormon. Perempuan memiliki kromosom $\mathrm{x}$ dan hormon progesteron yang berperan dalam memberikan kekebalan bawaan dan adaptif. Perempuan biasanya memiliki pengetahuan tentang faktor risiko COVID-19 yang lebih baik daripada laki-laki. Selain itu, ada dugaan lakilaki lebih banyak yang menjadi perokok aktif (Susilo et al., 2020).

\section{Infeksi Nosokomial di Rumah Sakit}

Interaksi antara pasien yang sakit COVID19, pegawai rumah sakit, dan pasien non COVID -19 sangat berpotensi dalam penularan COVID19. Oleh karena itu, WHO memberikan arahan tentang tata laksana pada penderita COVID-19 dengan menerapkan protokol kesehatan yang ketat. Pasien harus menggunakan masker. Pasien yang menderita COVID-19 ditempatkan dalam ruangan khusus yang berbeda dengan pasien umumnya. Untuk berinteraksi dengan orang lain, pasien diharuskan memberi jarak minimal satu meter. Petugas rumah sakit diwajibkan menggunakan Alat Pelindung Diri (APD) lengkap sesuai standar. Pasien pun tidak boleh dijenguk oleh keluarganya.

\section{Adanya penyakit komorbid}

Komorbid atau penyakit penyerta yang meningkatkan risiko terpapar covid adalah hipertensi, diabetes mellitus, kardiovaskuler, paru obstruktif kronik, penyakit hati kronik, dan kanker. Pengobatan hipertensi dilakukan dengan pemberian obat Angiotensin-converting enzyme (ACE) inhibitor dan angiotensin receptor blocker (ARB). ACE inhibitor menyebabkan virus dapat masuk ke dalam tubuh. Pengobatan hipertensi dengan ACE inhibitor dan ARB meningkatkan risiko morbiditas dan mortalitas COVID-19.

Pengobatan penyakit kardiovaskuler menggunakan obat yang mengandung ACE 2 dan ARB untuk melindungi paru-paru. Sementara protein ACE2 digunakan SARS-CoV2 sebagai jalan masuk ke dalam tubuh. Jadi, ACE 2 mempunyai 2 sisi. Pertama, ACE 2 menjadi pelindung bagi paru-paru. Kedua, ACE 2 sebagai jalan masuknya virus ke dalam tubuh yang dapat menyebabkan keracunan jantung.

Orang yang menderita diabetes mellitus kemudian terpapar COVID-19 akan berisiko mengalami penyakit yang berat dan parah. Penderita COVID-19 yang memiliki komorbid diabetes mellitus akan meningkatkan risiko kematian. Penyakit komorbid paru obstruktif kronik (POK) menjadi faktor risiko COVID-19 karena pengobatan POK menggunakan ACE dan ARB. Obat tersebut mempermudah masuknya SAR CoV 2 masuk ke dalam tubuh.

Penyakit komorbid lainnya adalah kanker dan penyakit hati kronik. Orang yang mengidap kanker dan penyakit hati kronik lebih mudah terinveksi COVID-19. Hal ini terkait adanya reaksi imunosupresif dan sitokin yang berlebihan karena kemoterapi dan pembedahan. Terjadi penurunan respons imun pada penderita penyakit hati kronik sehingga lebih mudah terjangkit COVID-19.

\section{Riwayat Merokok}

Ada penelitian menyebutkan merokok dapat meningkatkan risiko seseorang terpapar COVID-19. Hal ini terjadi karena merokok 
menyebabkan meningkatnya reseptor ACE 2 yang menyebabkan virus SAR CoV2 masuk ke dalam tubuh.

Berinteraksi Langsung dengan Penderita COVID19.

Secara umum, orang memiliki riwayat berpergian ke daerah terjangkit COVID-19 berisiko tertular COVID-19. Biasanya gejala akan muncul setelah 14 hari pulang dari perjalanannya. Selain itu, orang bisa terpapar COVID-19 jika melakukan kontak erat dengan orang positif COVID-19, baik saat sudah terdeteksi COVID-19, maupun sebelum orang tersebut terdeteksi COVID-19. Hal tersebut bisa terjadi pada orang yang tinggal serumah dengan penderita COVID-19 atau satu tempat kerja atau lingkungan rumah serta di lingkungan pelayanan kesehatan.

\section{Kepadatan Penduduk}

Hasil penelitian di DKI Jakarta periode Maret 2020 hingga Juli 2020 menunjukkan adanya hubungan kepadatan penduduk dengan jumlah kasus terkonfirmasi positif COVID-19. Hal ini disebabkan kepadatan penduduk dapat meningkatkan frekuensi interaksi antar penduduk (Edriani et al., 2021).

\section{METODE PENELITIAN}

Penelitian ini mengunakan pendekatan kuantitatif. Sumber data berasal dari data sekunder. Jumlah kasus COVID-19 per kecamatan di Kabupaten Pati menggunakan data awal pandemi sampai 1 November 2021 dari website covid19.patikab.go.id. yaitu sebanyak 9.842 kasus. Adapun data kasus konfirmasi positif COVID-19 berdasarkan golongan usia dan jenis kelamin di Kabupaten Pati menggunakan data kasus konfirmasi positif sejak awal pandemi sampai 31 Desember 2020 yang ada dalam laporan Profil Kesehatan Kabupaten Pati Tahun 2020 yaitu sebanyak 1.741 kasus. Pengolongan usia penderita COVID-19 dikelompokkan berdasarkan pengelompokan dari Dinas Kesehatan Kabupaten Pati (Dinas Kesehatan Kabupaten Pati, 2021). Data jumlah penduduk (jiwa) dan kepadatan penduduk (jiwa $/ \mathrm{km}^{2}$ ) tiap kecamatan di Kabupaten Pati menggunakan data dari Badan Pusat Statistik (Badan Pusat Statistik Kabupaten Pati, 2021).

Analisis data dilakukan secara deskriptif dan inferensial. Distribusi jumlah kasus COVID19 berdasarkan jenis kelamin dan golongan usia dianalisis secara deskriptif. Adapun pengaruh kepadatan penduduk tiap kecamatan terhadap jumlah kasus COVID-19 dianalisis dengan uji regresi linear sederhana dengan softwafe SPSS for windows versi 16.0.

\section{HASIL DAN PEMBAHASAN}

\section{Persebaran Kasus Berdasarkan Jenis Ke- lamin}

COVID-19 menyerang semua orang tanpa memandang jenis kelamin. Gambaran sebaran kasus COVID-19 berdasarkan jenis kelamin di Kabupaten Pati disajikan dalam Gambar 1.

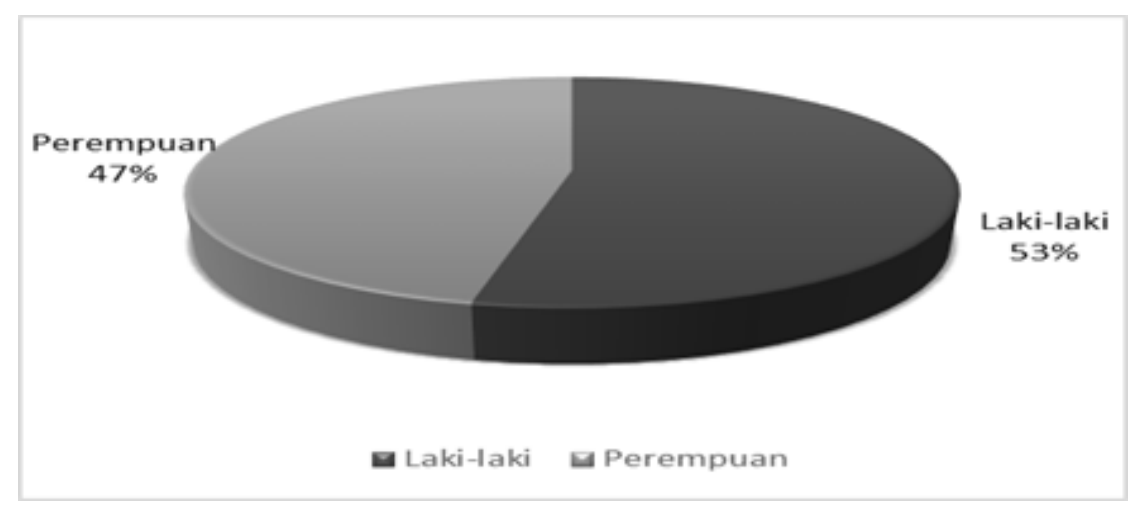

Gambar 1.

Persebaran Jumlah Kasus COVID-19 Berdasarkan Jenis Kelamin Sumber: Profil Kesehatan Kabupaten Pati (2021) 
Berdasarkan Profil Kesehatan Kabupaten Pati Tahun 2020, jumlah kasus COVID-19 di Kabupaten Pati sebanyak 1.741 orang, terdiri atas 931 laki-laki atau 53\% dan 810 perempuan atau $47 \%$. Data ini menunjukkan laki-laki lebih mudah terpapar COVID-19 dari pada perempuan. Hasil penelitian ini sesuai dengan penelitian (Styawan, 2021) yang menunjukkan bahwa laki-laki di Indonesia lebih rentan terpapar COVID-19 dari pada perempuan. Jumlah penduduk laki-laki yang terkonfirmasi positif covid-19 sebanyak 51,5\%, sedangkan perempuan sebanyak $48,5 \%$.

Salah satu upaya Pemerintah Kabupaten Pati untuk mencegah dan mengendalikan penyebaran COVID-19 dengan membuat kebijakan pedoman menuju tatanan normal baru pada masa pandemi COVID-19 di Kabupaten Pati yang tertuang dalam Peraturan Bupati Pati Nomor 49 Tahun 2020. Kebijakan tersebut berisi tentang pedoman pelaksanaan protokol kesehatan dalam aktivitas sehari-hari. Protokol kesehatan sebagai upaya mencegah penyebaran COVID-19, meliputi memakai masker, mencuci tangan pakai sabun dengan air mengalir atau memakai handsanitizer, menjaga jarak minimal 1,5 m (social distancing), menjauhi keramaian atau di rumah saja, dan tidak berpergian ke luar daerah terutama zona merah.

Penelitian oleh Sari, et al (2020) menunjukkan bahwa terdapat hubungan antara jenis kelamin dengan perilaku pencegahan COVID19. Perempuan cenderung lebih peduli terhadap kondisi lingkungan dan kesehatannya. Selain itu, perempuan juga memiliki pengetahuan yang lebih baik tentang pencegahan COVID-19 dibandingkan dengan laki-laki. Hal ini disebabkan perempuan memiliki lebih banyak waktu untuk membaca atau berdiskusi dengan lingkungannya terkait pencegahan COVID-19 (Wulandari et al., 2020).

Kondisi tersebut sesuai dengan hasil survei Badan Pusat Statistik Kabupaten Pati tahun 2020 yang menunjukkan ada perbedaan pemahaman tentang kebijakan new normal dalam pencegahan COVID-19 antara laki-laki dan perempuan di Kabupaten Pati. Perempuan $(56,3 \%)$ lebih memahami tentang adanya kebijakan new normal dari pada laki-laki $(47,3 \%)$. Selain itu, perempuan $(47,12 \%)$ lebih khawatir terhadap kesehatannya dibandingkan laki-laki (32,16\%). Perempuan (51,59\%) lebih khawatir ketika berada di luar rumah dibandingkan laki-laki (39,46\%). Adanya kekhawatiran ini menyebabkan perempuan lebih disiplin dalam menjaga kebersihan dengan menerapkan protokol kesehatan dalam masa new normal (Badan Pusat Statistik Kabupaten Pati, 2021).

Pengetahuan dan kesadaran masyarakat berkaitan dengan upaya pencegahan COVID-19 menjadi faktor yang memengaruhi kepatuhan masyarakat dalam menerapkan protokol kesehatan (Fuadi \& Irdalisa, 2020; Afrianti \& Rahmiati, 2021). Perbedaan perilaku laki-laki dan perempuan dalam menerapkan protokol kesehatan dapat menyebabkan jumlah kasus COVID-19 pada laki-laki lebih tinggi daripada kasus COVID-19 pada perempuan. Hal ini disebabkan perempuan relatif lebih taat dalam melaksanakan protokol kesehatan dibandingkan dengan laki-laki (Riyadi \& Larasaty, 2021; Widayati \& Mustika, 2021).

Siagian (2021) menyebutkan laki-laki lebih berisiko terpapar COVID-19 dari pada perempuan karena laki-laki banyak yang memiliki kebiasaan merokok. Kebiasaan merokok dapat mengubah sel paru menjadi lebih rentan terhadap infeksi SARS-COV2 melalui peningkatan reseptornya yaitu molekul ACE 2. Profil Kesehatan Kabupaten Pati (2020) menunjukkan 22,54\% penduduk di Kabupaten Pati memiliki kebiasaan merokok setiap hari. Jumlah batang rokok yang dihisap dalam seminggu rata-rata sebanyak 91,39 batang. Diperkirakan penduduk yang merokok di Kabupaten Pati menghabiskan rokok sebanyak 13 batang rokok per hari. 
Laki-laki lebih rentan terpapar COVID-19 dari pada perempuan bisa juga disebabkan mobilitas laki-laki yang lebih tinggi dari pada perempuan (Warsida, Adioetomo, \& Pardede, 2013). Secara umum masyarakat memiliki pandangan bahwa laki-laki bertanggung jawab memenuhi kebutuhan anggota keluarganya. Sementara, perempuan cenderung lebih banyak melaksanakan aktivitas domestik di rumah (Kismono, Rosari, \& Suprihanto, 2014). Perbedaan kromosom laki-laki dan perempuan menyebabkan laki-laki lebih mudah terpapar COVID-19. Kromosom X lebih dominan pada perempuan (XX) daripada laki-laki (XY). Kromosom $X$ memiliki keterkaitan dengan banyak gen yang terlibat dalam sistem imun sehingga perempuan memiliki sistem imun yang lebih baik dari pada laki-laki (Seftiya \& Kosala, 2021).

\section{Persebaran Kasus Berdasarkan Golongan Usia}

COVID-19 menyerang semua orang di semua kelompok usia. Sebaran kasus COVID-19 berdasarkan golongan usia di Kabupaten Pati disajikan dalam Gambar 2. Berdasarkan Profil Kesehatan Kabupaten Pati Tahun 2020, kasus COVID-19 di Kabupaten Pati sejak awal pandemi sampai dengan 31 Desember 2020 sebanyak 1.741 orang tersebar dalam semua golongan usia.

Berdasarkan Gambar 2, kasus COVID-19 pada usia 18 tahun ke bawah rendah yaitu sebanyak 56 kasus atau 3,2\%. Adapun kasus COVID-19 pada golongan usia 19 tahun ke atas sangat tinggi yaitu 1685 kasus atau 96,8\%. Kasus COVID-19 terbanyak pada golongan usia 46 -59 tahun yaitu sebanyak 637 orang $(36,59 \%)$ diikuti golongan usia 31-45 tahun yaitu sebanyak 482 orang $(27,69 \%)$. Selanjutnya golongan usia $60+$ tahun atau lanjut usia sebanyak 354 orang $(20,33 \%)$. Jika penderita COVID-19 ini dikelompokkan dalam usia produktif dan non produktif, maka sebagian besar penderita Covid-19 adalah usia produktif. Usia produktif adalah kelompok penduduk yang berusia antara 15-65 tahun (Ros Maria \& Raharjo, 2020). Hasil penelitian ini sama dengan penelitian di ruang isolasi COVID-19 RSMH Palembang yang menunjukkan sebagian besar pasien termasuk usia produktif. Usia produktif lebih mudah terpapar COVID-19 karena faktor mobilitas dan tingginya aktivitas di luar rumah. Selain itu pada usia produktif lebih banyak dan lebih sering mengadakan interaksi dengan orang lain (Elviani et al., 2021).

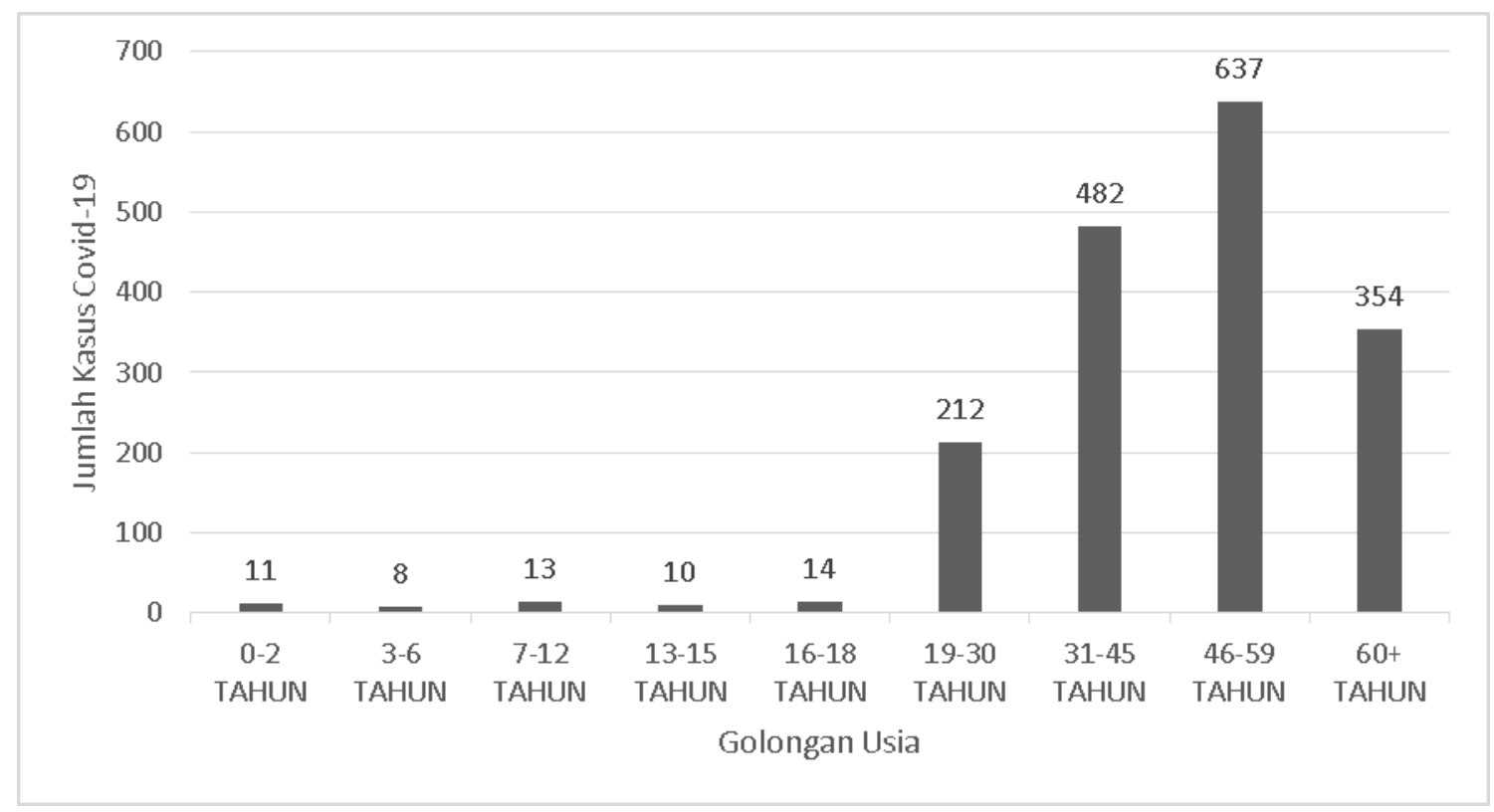

Gambar 2.

Persebaran Jumlah Kasus COVID-19 Berdasarkan Golongan Usia Sumber: Profil Kesehatan Kabupaten Pati (2021) 
Kelompok lansia atau usia 60 tahun ke atas cukup tinggi, yaitu $20,33 \%$ dari total kasus. Lansia dibagi menjadi empat kelompok menurut batasan WHO, yaitu usia pertengahan (45-49 tahun), lanjut usia (60-74 tahun), lanjut usia tua (75-90 tahun) dan usia sangat tua (lebih dari 90 tahun). Berdasarkan batasan tersebut, maka yang dimaksud lansia adalah seseorang yang berusia di atas 60 tahun (Naftali, Ranimpi, \& Anwar, 2017). Lansia termasuk salah satu kelompok yang berisiko terpapar COVID-19. Hal ini terjadi karena lanjut usia memiliki daya tahan tubuh yang cenderung semakin melemah. Akibatnya lansia tidak mampu melawan infeksi yang masuk ke dalam tubuh termasuk COVID-19. Selain itu, lansia cenderung memiliki banyak masalah kesehatan yang dapat memperparah kondisinya jika terpapar COVID-19 (Elviani et al., 2021).

\section{Persebaran Kasus COVID-19 Berdasarkan Kepadatan Penduduk}

Berdasarkan Profil Kesehatan Kabupaten Pati Tahun 2020, jumlah penduduk Kabupaten Pati yang terpapar COVID-19 sejak awal pandemi (Maret 2020) sampai dengan akhir bulan Desember 2020 sebanyak 1.741 orang (Dinas Kesehatan Kabupaten Pati, 2021). Penduduk yang terpapar COVID-19 terus bertambah. Berdasarkan data dari covid19.patikab.go.id (2021), penduduk yang terpapar COVID-19 di Kabupaten Pati sampai tanggal 1 November 2021 berjumlah 9.841 orang. penduduk yang terpapar COVID-19 di Kabupaten Pati tersebar dalam 21 kecamatan sebagaimana disajikan dalam Gambar 3.

Berdasarkan Gambar 3 terlihat bahwa kasus COVID-19 di Kabupaten Pati dapat ditemukan di seluruh Kecamatan. Kecamatan dengan jumlah kasus COVID-19 paling banyak adalah Kecamatan Pati, yaitu sebanyak 1.857 orang. Sementara itu, kecamatan dengan jumlah kasus COVID-19 paling sedikit adalah Kecamatan Pucakwangi dengan jumlah kasus COVID-19 sebanyak 154 orang.

Penambahan kasus baru sudah melambat namun masih tetap ada. Upaya pencegahan dengan penerapan protokol kesehatan masih harus tetap dilakukan. Terdapat peringatan bahwa kasus COVID-19 diprediksi akan meningkat kembali pada bulan Desember 2021 karena ada liburan akhir tahun. Ketika momen liburan, sering kali masyarakat abai dalam menerapkan protokol kesehatan khususnya social distancing.

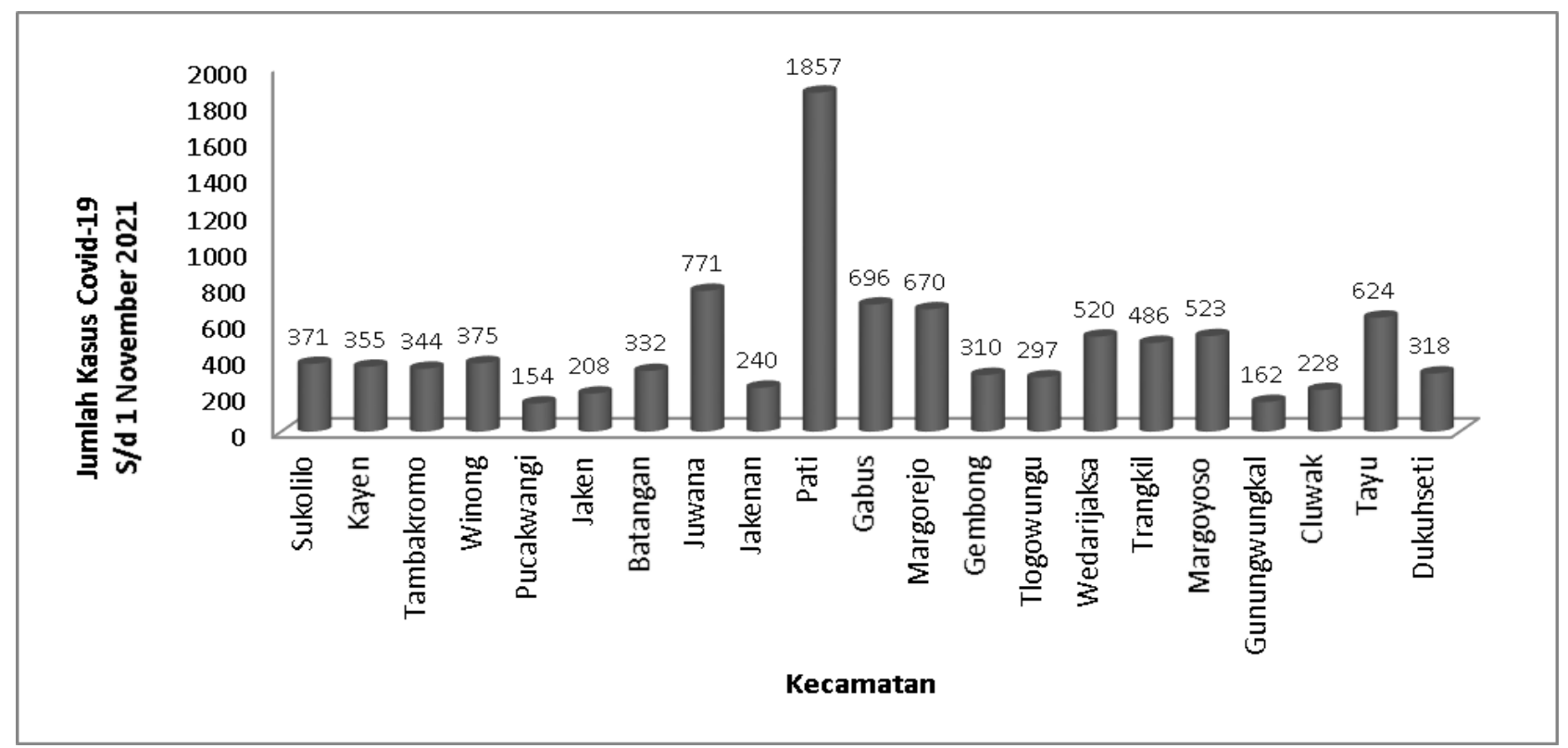

Gambar 3

Persebaran Jumlah Kasus COVID-19 Tiap Kecamatan Per 1 November 2021

Sumber: https://covid19.patikab.go.id/v4/per tanggal 1 November 2021 
Kabupaten Pati terbagi dalam 21 kecamatan dengan luas wilayah yang berbeda-beda. Kecamatan Sukolilo memiliki wilayah paling luas dengan luas $158,74 \mathrm{~km}^{2}$. Kecamatan dengan wilayah paling kecil adalah Kecamatan Pati dengan luas wilayah $42,49 \mathrm{~km}^{2}$. Berdasarkan sensus tahun 2020, Kecamatan Pati memiliki jumlah penduduk paling banyak yaitu 108.398 orang. Oleh karenanya, Kecamatan Pati memiliki kepadatan penduduk paling tinggi dibandingkan kecamatan lainnya (Tabel 1).

Salah satu unsur lingkungan yang memempengaruhi terjadinya penyakit menular adalah kepadatan penduduk. Hal ini berkaitan dengan proses penularan penyakit. Penyakit yang penularannya melalui udara (droplet) akan cepat menyebar pada daerah dengan kepadatan penduduk tinggi (Mardiana, 2018). Tingginya tingkat kepadatan penduduk suatu daerah juga meningkatkan frekuensi interaksi antar individu pada daerah tersebut (Edriani et al., 2021). COVID-19 merupakan salah satu penyakit yang ditularkan melalui droplet. Interaksi yang erat akan meningkatkan risiko penularan. Data kepadatan penduduk dan jumlah kasus COVID-19 tiap kecamatan di Kabupaten Pati disajikan dalam Tabel 1.

Kecamatan Pati merupakan kecamatan terpadat di Kabupaten Pati yaitu 2.552,14 jiwa $/ \mathrm{km}^{2}$. Kecamatan terpadat kedua adalah Kecamatan Juwana dengan 1.715,22 jiwa/ $\mathrm{km}^{2}$. Kecamatan dengan kepadatan terendah adalah Kecamatan Pucakwangi yaitu yaitu 390,25 jiwa $/ \mathrm{km}^{2}$. Adapun jumlah kasus COVID-19 terbanyak di Kecamatan Pati yaitu 1.857 orang, posisi kedua Kecamatan Juwana dengan 771 orang. Kecamatan dengan kasus terendah adalah Kecamatan Pucakwangi yaitu 154 orang.

Tabel 1.

Kepadatan Penduduk dan Jumlah Kasus COVID-19 Tiap Kecamatan di Kab Pati Per 1 November 2021

\begin{tabular}{clrccc}
\hline No & Kecamatan & $\begin{array}{c}\text { Jumlah } \\
\text { Penduduk }\end{array}$ & $\begin{array}{c}\text { Luas } \\
\mathbf{( \mathbf { k m } ^ { 2 } \mathbf { ) }}\end{array}$ & $\begin{array}{c}\text { Kepadatan } \\
\text { (Jiwa/km } \mathbf{~}\end{array}$ & $\begin{array}{c}\text { Jumlah Kasus } \\
\text { COVID-19 }\end{array}$ \\
\hline 1 & Sukolilo & 90.270 & 158,74 & 568,67 & 371 \\
2 & Kayen & 78.540 & 96,04 & 817,78 & 355 \\
3 & Tambakromo & 55.616 & 72,47 & 767,43 & 344 \\
4 & Winong & 63.638 & 99,94 & 636,76 & 375 \\
5 & Pucakwangi & 47.934 & 122,83 & 390,25 & 154 \\
6 & Jaken & 46.174 & 68,52 & 673,88 & 208 \\
7 & Batangan & 44.619 & 50,66 & 880,75 & 332 \\
8 & Juwana & 95.933 & 55,93 & 1715,22 & 771 \\
9 & Jakenan & 47.568 & 53,04 & 896,83 & 240 \\
10 & Pati & 108.398 & 42,49 & 2551,14 & 1.857 \\
11 & Gabus & 62.279 & 55,51 & 1121,94 & 696 \\
12 & Margorejo & 64.091 & 61,81 & 1036,90 & 670 \\
13 & Gembong & 47.370 & 67,30 & 703,86 & 310 \\
14 & Tlogowungu & 54.300 & 94,46 & 574,85 & 297 \\
15 & Wedarijaksa & 63.808 & 40,85 & 1562,01 & 520 \\
16 & Trangkil & 63.275 & 42,84 & 1477,01 & 486 \\
17 & Margoyoso & 74.267 & 59,97 & 1238,04 & 523 \\
18 & Gunungwungkal & 37.898 & 61,80 & 613,24 & 162 \\
19 & Cluwak & 47.338 & 69,31 & 682,99 & 228 \\
20 & Tayu & 70.022 & 47,59 & 1471,36 & 624 \\
21 & Dukuhseti & 60.850 & 81,59 & 745,80 & 318 \\
\hline & Jumlah & 1.324 .188 & $1.503,68$ & 880,63 & 9.841 \\
\hline
\end{tabular}

Sumber: BPS Kab. Pati (2021), website covid19.patikab.go.id (1 November 2021) 
Selanjutnya, kepadatan penduduk tiap kecamatan diuji pengaruhnya terhadap jumlah kasus COVID-19 tiap kecamatan. Uji statistik menggunakan uji regresi linear sederhana dengan bantuan program SPSS for Windows versi 16.0.

Langkah pertama adalah melakukan uji normalitas dengan uji Kolmogorov-Smirnov. Nilai Kolmogrov Smirnov sebesar 0,406 dengan tingkat signifikansi residual sebesar 0,996. Nilai signifikansi residual lebih besar dari 0,05 yang berarti data memiliki distribusi normal dan memenuhi prasyarat uji asumsi klasik sehingga dapat dilakukan uji regresi linear sederhana.

Langkah berikutnya adalah melakukan uji linieritas. Hasil uji linieritas menunjukkan signifikansi Deviation from Linearity sebesar 0,232 . Nilai 0,232 lebih besar dari 0,05 . Artinya data variabel bebas dan variabel terikat memiliki hubungan yang linear sehingga dapat dilakukan uji regresi linear sederhana. Uji statistik regresi linear sederhana menunjukkan korelasi antara variabel kepadatan penduduk dengan jumlah penderita COVID-19 per kecamatan di Kabupaten Pati (Tabel 2). Persamaan persamaan regresi dapat ditulis:

$$
\begin{aligned}
& Y=-168,103+6,328 X \text { atau dapat ditulis } \\
& Y=6,328 X-168,103 .
\end{aligned}
$$

Nilai Koefisien b adalah 6,328 maka model regesi bernilai positif atau searah. Jika kepadatan penduduk naik, maka jumlah kasus covid 19 meningkat. Hasil uji regresi linear sederhana menunjukkan nilai signifikansi 0,000 lebih kecil dari 0,05 $(0,000<0.05)$. Angka ini menunjukkan variabel kepadatan penduduk berpengaruh terhadap tingginya jumlah penderita COVID-19 di Kabupaten Pati.

Kuatnya pengaruh variabel bebas terhadap variabel terikat dapat dilihat dari nilai koefisien korelasi (R). Adapun besarnya kontribusi variabel bebas terhadap variabel terikat ditunjukkan oleh koefisien determinasi (R2). Nilai koefisien korelasi dan koefisien determinasi antara nol dan satu. Nilai koefisien yang mendekati nilai 1 menunjuknya kuatnya pengaruh variabel bebas terhadap variabel terikat.

Tabel 3. menunjukkan bahwa nilai $r$ atau koefisien korelasi sebesar 0,890. Angka tersebut menunjukkan hubungan kepadatan penduduk dengan tingginya jumlah penderita COVID-19 sangat erat. Nilai koefisien determinasi (R2) yang diperoleh sebesar 0,793. Hal ini berarti bahwa $79 \%$ tingginya jumlah penderita COVID-19 dipengaruhi oleh kepadatan penduduk. Adapun sisanya yaitu sebesar $21 \%$ dipengaruhi oleh variabel-variabel lainnya yang tidak diteliti dalam penelitian ini.

Tabel 2.

Hasil Perhitungan Regresi Linear Sederhana

\begin{tabular}{ccccccc}
\hline \multirow{2}{*}{ Model } & \multicolumn{2}{c}{$\begin{array}{c}\text { Unstandardized Coeffi- } \\
\text { cients }\end{array}$} & $\begin{array}{c}\text { Standardized } \\
\text { Coefficients }\end{array}$ & t & Sig. \\
\cline { 2 - 5 } & \multicolumn{1}{c}{ B } & Std. Error & Beta & & \\
\hline \multirow{2}{*}{1} & -168.103 & 83.434 & & -2.015 & .058 \\
& $\begin{array}{l}\text { (Constant) } \\
\text { Kepadatan } \\
\text { Penduduk }\end{array}$ & 6.328 & .742 & .890 & 8.523 & .000 \\
\hline
\end{tabular}

a.

Dependent Variable: Jumlah COVID-19

Tabel 3.

Koefisien Korelasi dan Koefisien Determinasi

\begin{tabular}{lcccc}
\hline Model & $\mathbf{R}$ & R Square & Adjusted R Square & Std. Error of the Estimate \\
\hline 1 & $.890^{\mathrm{a}}$ & .793 & .782 & 170.219 \\
\hline
\end{tabular}

a. Predictiors: (Constat), $\mathrm{X} 2$ 
Hasil penelitian selaras dengan hasil penelitian di DKI Jakarta yang menunjukkan ada hubungan erat antara kepadatan penduduk dengan kasus konfirmasi COVID-19. Variabel kepadatan penduduk memberi pengaruh terhadap jumlah kasus terkonfirmasi positif COVID-19 sebesar 50.8\% (Edriani et al., 2021). Penelitian lain menunjukkan faktor mobilitas baik dalam kota maupun ke luar kota menjadi salah faktor yang mempengaruhi penyebaran COVID-19 di DKI Jakarta.

\section{KESIMPULAN DAN SARAN}

\section{Kesimpulan}

Penderita COVID-19 paling banyak di Kecamatan Pati yaitu sebanyak 1.857 orang. Sebanyak 53\% Penderita COVID-19 berjenis kelamin laki-laki. Kasus COVID-19 sebagian besar menyerang usia produktif, terbanyak pada golongan usia 46-59 tahun yaitu sebanyak 637 orang (36,59\%). Ada pengaruh yang kuat kepadatan penduduk terhadap tingginya kasus COVID-19 dengan koefisien korelasi (R) sebesar 0,890. Tingginya jumlah penderita COVID19 di Kabupaten Pati, 79\%-nya dipengaruhi oleh faktor kepadatan penduduk (nilai R2= 0,793).

\section{Saran}

Pandemi COVID-19 belum berakhir. Upaya pencegahan harus selalu dilakukan dengan memberikan sosialisasi tentang penerapan protokol kesehatan pada masyarakat khususnya kecamatan yang padat penduduknya. Penyuluhan pada laki-laki menekankan upaya untuk tidak merokok. Penyuluhan pada lansia menekankan untuk meningkatkan daya tahan tubuh dengan memenuhi asupan makanan dan melakukan vaksinasi.

\section{DAFTAR PUSTAKA}

Aeni, N. (2021). Pandemi COVID-19: Dampak Kesehatan, Ekonomi, \& Sosial. Jurnal Litbang: Media Informasi Penelitian, Pengembangan dan IPTEK, 17(1), 17-34. https://doi.org/10.33658/jl.v17i1.249.
Afrianti, N., \& Rahmiati, C. (2021). FaktorFaktor yang Mempengaruhi Kepatuhan Masyarakat Terhadap Protokol Kesehatan Covid-19. Jurnal Ilmiah Permas: Jurnal Ilmiah STIKES Kendal, 11(1), 113124. https://doi.org/10.32583/pskm.v11 i1.1045.

Amalia, A., \& Sa'adah, N. (2020). Dampak Wabah Covid-19 Terhadap Kegiatan Belajar Mengajar di Indonesia. Jurnal Psikologi, 13(2), 214-225. https://doi.org/10. 35760/psi.2020.v13i2.3572.

Arif, M., Amalia, E., Sesrianty, V., Maidaliza, M., \& Kartika, K. (2020). Pemberian Edukasi Tentang Pencegahan Infeksi Virus Corona Melalui Etika Batuk dan Penggunaan Masker yang Benar di SMA Al Islah Bukittinggi. Jurnal Abdimas Kesehatan Perintis, 2(1), 70-75. Retrieved from https://jurnal.stikesperintis.ac.id/ index.php/JAKP/article/view/461.

Astuti, N. P., Nugroho, E. G. Z., Lattu, J. C., Potempu, I. R., \& Swandana, D. A. (2021). Persepsi Masyarakat terhadap Penerimaan Vaksinasi Covid-19: Literature Review. Jurnal Keperawatan, 13(3), 569580.https://doi.org/10.32583/keperawatan. v13i3.1363,

Badan Pusat Statistik Kabupaten Pati. (2020). Profil Masyarakat Kabupaten Pati di Era New Normal: Analisis Hasil Survei Sosial Ekonomi Dampak Covid-19 Pati .

Badan Pusat Statistik Kabupaten Pati. (2021). Kabupaten Pati dalam Angka.

Dinas Kesehatan Kabupaten Pati. (2021). Profil Kesehatan Kabupaten Pati Tahun 2020.

Badan Pusat Statistik Kabupaten Pati. (2020). Profil Kesehatan Kabupaten Pati 2020.

Edriani, T. S., Rahmadani, A., \& Noor, D. M. M. (2021). Analisis Hubungan Kepadatan Penduduk dengan Pola Penyebaran COVID-19 Provinsi DKI Jakarta menggunakan Regresi Robust. Indonesian Journal of Applied Mathematics, 1(2), 51. https://doi.org/10.35472/indojam. v1i2.353. 
Elviani, R., Anwar, C., \& Sitorus, R. J. (2021). Gambaran Usia pada Kejadian Covid-19. Jambi Medical Jurnal, 9(2), 204-209. https://doi.org/10.22437/jmj.v9i1.112 63

Fuadi, T. M., \& Irdalisa. (2020). Covid 19: Antara Angka Kematian dan Angka Kelahiran. Jurnal Sosiologi Agama Indonesia, 1 (3), 199-211. https://doi.org/10.22373/ jsai.v1i3.767.

Ghiffari, R. A. (2020). Dampak Populasi dan Mobilitas Perkotaan Terhadap Penyebaran Pandemi Covid-19 di Jakarta. Tunas Geografi, 9(1), 81-88. https://doi. org/10. 24114/tgeo. v9i1. 18622.

Gunardi, W. D. (2021). Pemeriksaan Diagnosis Laboratorium COVID-19: Keterbatasan dan Tantangannya Saat Ini Laboratory Diagnostic Tests for COVID-19: Current Limitations and Challenges. Jurnal Kedokteran Meditek, 27(2), 173-182.

Hidayani, W. R. (2020). Faktor-Faktor Risiko yang Berhubungan dengan COVID 19: Literature Review. Jurnal Untuk Masyarakat Sehat (JUKMAS), 4(2), 120-134. https://doi.org/10.52643/jukmas.v4 i2. 1015.

Illah, M. N. N. (2021). Analisis Pengaruh Komorbid, usia, dan Jenis kelamin Terhadap Meningkatnya Angka Kematian pada Masa Pandemi Covid-19. Jurnal Sosial dan Sains (SOSAINS), 1(10), 1228-1233. https://doi.org/10.36418/ sosains.v1i10.232

Ilpaj, S. M., \& Nurwati, N. (2020). Analisis Pengaruh Tingkat Kematian Akibat Covid -19 Terhadap Kesehatan Mental Masyarakat di Indonesia. Focus : Jurnal Pekerjaan Sosial, 3(1), 16. https:// doi.org/ 10.24198/focus.v3i1.28123.

Kemenkes RI. (2020). Pedoman Pembedayaan Masyarakat Dalam Pencegahan COVID-19 di RT/RW/Desa. Retrieved from https:// infeksiemerging.kemkes.go.id. download/ BUKU_PEDOMAN_RT_RW_Pencegahan_ COVID.pdf.
Kismono, G., Rosari, R., \& Suprihanto, J. (2014). Faktor-Faktor Demografik (Jenis Kelamin, Usia, Status Pernikahan, Dukungan Domestik) Penentu Konflik Pekerjaan dan Keluarga dan Intensi Keluar Karyawan: Studi pada Industri Perbankan Indonesia. Jurnal Siasat Bisnis, 17(2), 208224.https://doi.org/10.20885/jsb.vol17.i ss2.art6.

Kresna, A., \& Ahyar, J. (2020). Pengaruh Physical Distancing dan Social Distancing Terhadap Kesehatan dalam Pendekatan Linguistik. Jurnal Syntax Transformation, 1 (4), 14-19. https://doi.org/10.46799/ jurnalsyntax transformation.v1i4.42.

Levani, Y., Prastya, A. D., \& Mawaddatunnadila, S. (2021). Coronavirus Disease 2019 (COVID-19): Patogenesis, Manifestasi Klinis dan Pilihan Terapi. Jurnal Kedokteran dan Kesehatan, 17(1), 44-57. https:// doi.org/10.24853/jkk.17.1.44-57.

Mardiana, D. E. (2018). Pengaruh Imunisasi dan Kepadatan Penduduk Terhadap Prevalensi Penyakit Difteri di Jawa Timur. Jurnal Berkala Epidemiologi, 6(2), 122. https://doi.org/10.20473/jbe.v6i22018. 122-129.

Naftali, A. R., Ranimpi, Y. Y., \& Anwar, M. A. (2017). Kesehatan Spiritual dan Kesiapan Lansia dalam Menghadapi Kematian. Buletin Psikologi, 25(2), 124-135. https://doi.org/10.22146/buletin psikologi.28992.

Nugroho, S. A., \& Hidayat, I. N. (2021). Efektivitas dan Keamanan Vaksin Covid-19: Studi Referensi. Jurnal Keperawatan Profesional, 9(2), 39-60. https://doi.org/ 10.336 50/jkp.v9i2.2767.

PDPI, PERKI, PAPDI, PERDATIN, \& IDAI. (2020). Pedoman Tata Laksana COVID-19 Edisi 3 Desember 2020. Pedoman Tatalaksana COVID-19. Retrieved from https://www. papdi.or.id/download/983-pedomantatalaksana-covid-19-edisi-3-desember2020. 
Rahmi, M. F., Prasetyo, P. S., Nurhabibah, R., Perdana, R., Ode, W., \& Madjida, Z. (2020). Pengelompokkan Provinsi di Indonesia Berdasarkan Jumlah Kasus Covid-19 dan Fasilitas Kesehatan. Jurnal Aplikasi Statistika \& Komputasi Statistik, 13(1), 47-56. https://doi.org/10.34123/jurnal asks.v13i1.274.

Ridwan, H., Darmawati, I., \& Rahmawati, M. N. (2020). Implementasi Kebijakan Physical Distancing dalam Pelaksanaan UTBK SBMPTN di Perguruan Tinggi. Jurnal Kebijakan Kesehatan Indonesia: JKKI, 9(4), 197-201. https://doi.org/10.22146 / jkki.59689.

Riyadi, R., \& Larasaty, P. (2021). Faktor Yang Berpengaruh Terhadap Kepatuhan Masyarakat Pada Protokol Kesehatan Dalam Mencegah Penyebaran Covid-19. Seminar Nasional Official Statistics, (1),45-54. https://doi.org/10.34123 / semnasoffstat.v2020i1.431.

Ros Maria, G. A., \& Raharjo, S. T. (2020). Adaptasi Kelompok Usia Produktif Saat Pandemi Covid-19 Menggunakan Metode Reality Therapy. Jurnal Kolaborasi Resolusi Konflik, 2(2), 142-149. https:// doi.org/10.24198/jkrk.v2i2.29124.

Sari, A. R., Rahman, F., Wulandari, A., Pujianti, N., Laily, N., Anhar, V. Y., Anggraini, L, Azmiyannoor, M., Ridwan, A. M., Muddin, F. I. (2020). Perilaku Pencegahan Covid19 Ditinjau dari Karakteristik Individu dan Sikap Masyarakat.. JPPKMI Uurnal Penelitian Dan Pengembangan Kesehatan Masyarakat Indonesia), 1(1), 32-37. https://journal.unnes. ac.id/sju/index. php/jppkmi.

Sari, L. M., Yaslina, Y., \& Suryati, I. (2020). Edukasi Kesehatan tentang Infeksi Virus Corona. Jurnal Abdimas Kesehatan Perintis, 2(1), 58-63.

Seftiya, A., \& Kosala, K. (2021). Epidemiologi Karakteristik Pasien Covid-19 di Kalimantan Utara. Jurnal Sains Kesehatan, 3 (5), 645-653. https://doi.org/10.25026 / Jsk.V3i5.542.
Siagian, T. H. (2020). Mencari Kelompok Berisiko Tinggi Terinfeksi Virus Corona dengan Discourse Network Analysis. Jurnal Kebijakan Kesehatan Indonesia, 9(2), 98106.. https://doi.org/10.22146/jkki.5 5475.

Sofianto, A. (2021). Pemahaman dan Implementasi Masyarakat tentang Protokol Kesehatan Covid-19 di Jawa Tengah, Indonesia. Jurnal Ekologi Kesehatan Indonesia, 20(2), 80-103. https:// doi.org/10.22435/jek.v20i2.4731.

Styawan, D. A. (2021). Pandemi Covid-19 dalam Perspektif Demografi. Seminar Nasional Official Statistics, 2020(1), 182-189. https://doi.org/10.34123/ semnasoffstat.v2020i1.716.

Susanto, N. (2021). Perbedaan Kasus Covid-19 pada Masa Lockdown dan New Normal di Indonesia. Jurnal Kesehatan Vokasional, 6 (3), 182-189. https://doi.org/10.22146/ jkesvo.62889.

Susilo, A., Rumende, C. M., Pitoyo, C. W., Santoso, W. D., Yulianti,M., Herikurniawan, Sinto, R., Singh, G., Nainggolan, L., Nelwan, E. J., Chen, L. K., Widhani, A., Wijaya, E., Wicaksana, B., Maksum, M., FAnnisa, F., Jasirwan, C. O. M., \& Yunihastuti, E. (2020). Coronavirus Disease 2019: Tinjauan Literatur Terkini. Jurnal Penyakit Dalam Indonesia, 7(1), 45. https:// doi.org/10. 7454/jpdi.v7i1.415.

Tuwu, D., Laksmono, B. S., Huraerah, A., \& Harjudin, L. (2021). Dinamika Kebijakan Penanganan Pandemi COVID-19 dalam Perspektif Kesejahteraan Sosial. Sosio Konsepsia, 10(2), 97-110. https:// doi.org/ 10.33007/ska.v10i2.2158.

Warsida, R. Y., Adioetomo, S. M., \& Pardede, E. (2013). Pengaruh Variabel SosioDemografis terhadap Mobilitas UlangAlik di Jabodetabek. Jurnal Ekonomi Dan Pembangunan Indonesia, 13(2), 159-176. https://doi.org/10.21002/jepi.v13i2.489.

Widayati, L. P., \& Mustika, I. (2021). Sikap Remaja terhadap Upaya Pencegahan Penyebaran Covid19 pada Orang Tanpa Gejala (OTG) di Surabaya. JI-KES Jurnal Ilmu Kesehatan), 4(2), 36-44. https:// doi.org/10.33006/ji-kes.v4i2.171. 
Wulandari, A., Rahman, F., Pujianti, N., Sari, A. R., Laily, N., Anggraini, L., Muddin, F. I., Ridwan, A. M., Anhar, V. Y., Azmiyannoor, M., Prasetio, D. B. (2020). Hubungan Karakteristik Individu dengan Pengetahuan tentang Pencegahan Coronavirus Disease 2019 pada Masyarakat di Kalimantan Selatan. Jurnal Kesehatan Masyarakat Indonesia, 15(1), 42-46. https://doi.org/10.26714/jkmi.15. 1.2020.42-46.

Zuhroidah, I., Toha, M., \& Sujarwadi, M. (2021). Pengetahuan Tentang Penularan COVID19 dan Kepatuhan Cuci Tangan Pakai Sabun. Jurnal Keperawatan, 13(1), 213226.

\section{BIODATA PENULIS}

Aeda Ernawati, lahir pada tanggal 22 November 1976 di Purworejo. Magister Gizi Masyarakat dari Universitas Diponegoro, Peneliti pada Badan Perencanan Pembangunan Daerah Kabupaten Pati 